\title{
Mineralocorticoid receptor antagonists therapy in resistant hypertension: time to implement guidelines!
}

\section{Giuseppe Maiolino*, Matteo Azzolini and Gian Paolo Rossi}

Department of Medicine (DIMED), Internal Medicine 4, University of Padova, Padova, Italy

Edited by:

Brett M. Mitchell, Texas A\&M Health

Science Center, USA

\section{Reviewed by:}

Piyali Chatterjee, Baylor Scott and

White Health, USA

Cristiana Catena, University of Udine, Italy

Jane A. Leopold, Harvard Medical

School, USA

\section{*Correspondence}

Giuseppe Maiolino, Department of Medicine (DIMED), Internal Medicine

4, University Hospital via Giustiniani

2, Padova 35126, Italy

e-mail: giuseppe.maiolino@gmail.com
Despite the availability of anti-hypertensive medications with increasing efficacy up to $50 \%$ of hypertensive patients have blood pressure levels (BP) not at the goals set by international societies. Some of these patients are either not optimally treated or are non-adherent to the prescribed drugs. However, a proportion, despite adequate treatment, have resistant hypertension $(\mathrm{RH})$, which represents an important problem in that it is associated to an excess risk of cardiovascular events. Notwithstanding a complex pathogenesis, an abundance of data suggests a key contribution for the mineralocorticoid receptor (MR) in $\mathrm{RH}$, thus fostering a potential role for its antagonists in $\mathrm{RH}$. Based on these premises randomized clinical trials aimed at testing the efficacy of MR antagonists (MRAs) in $\mathrm{RH}$ patients have been completed. Overall, they demonstrated the efficacy of MRAs in reducing BP and surrogate markers of target organ damage, such as microalbuminuria, either compared to placebo or to other drugs. In summary, owing to the key role of the MR in the pathogenesis of $\mathrm{RH}$ and on the proven efficacy of MRAs we advocate their inclusion as an essential component of therapy in patients with presumed $\mathrm{RH}$. Conversely, we propose that $\mathrm{RH}$ should be diagnosed only in patients whose BP values show to be resistant to an up-titrated dose of these drugs.

Keywords: mineralocorticoid receptor antagonists, pathogenesis, resistant hypertension, therapy, review

\section{RESISTANT HYPERTENSION: WANDERING DEFINITIONS ARE NOT HELPFUL}

The development of novel anti-hypertensive medications with increasing efficacy and decreasing adverse effects might generate the deceitful impression that decreasing patients' blood pressure (BP) at the goals set by international societies is no longer an issue. By contrast, available data indicate just the opposite, as recently confirmed by an analysis of the National Health and Nutrition Examination Survey (NHANES) showing that only $53 \%$ of treated hypertensive participants had BP at goal (1), as well as by a crosssectional analysis of the Framingham Heart Study and a recent study including 172,432 subjects in which only from 48 to $64 \%$ of treated patients had BP at goal $(2,3)$. While differences in these rates $(7.6-18 \%)$ likely reflect several factors, including, above all, the stringency of the criteria used $(4,5)$, it is clear that not all of the hypertensive patients with uncontrolled $\mathrm{BP}$ values have resistant hypertension (RH) and represent therapeutic failures. Good deals of them are either not optimally treated (6) or are non-adherent to the prescribed drugs (7-9) or are taking medications that can raise BP [see for review Rossi et al. (10)]. Therefore, they should be more appropriately considered medical failures. However, the subset of patients that have RH according to the definitions of the international societies (Table 1) represent an important medical problem as they are exposed to progressive damage in the target organs (11) and thereby to an excess risk of cardiovascular events as recently reemphasized by a post hoc analysis of the ALLHAT database (12).

All the current guidelines define RH, albeit with slight differences (Table 1), by the inability to lower BP levels at goal with a treatment including at least three drugs of different classes, one being ideally (13) or necessarily (14-16) a diuretic, all prescribed at optimal doses. The American Heart Association (AHA) definition is even less restrictive in that it defines as RH patients those on more than three medications, even though their BP is at target (13). It is worth to underline that only the European Society of Hypertension (ESH) guidelines pay heed to the implementation of appropriate lifestyle changes (14), a treatment option neglected in the others $(13,15,16)$. The measures associated to a better BP control are: (1) salt restriction [systolic and diastolic BP reduction of $6 / 3 \mathrm{mmHg}$ up to $20 / 10 \mathrm{mmHg}$, respectively (17)]; (2) diet reduced on saturated fat/cholesterol and increased on vegetables, fruits, and fish $[5 / 3 \mathrm{mmHg}$ of systolic and diastolic $\mathrm{BP}$ reduction, respectively (18)]; (3) weight reduction [1 $\mathrm{mmHg}$ of BP decrease per kilogram of weight loss (19)]; (4) aerobic physical exercise [7/5 mmHg of systolic and diastolic BP reduction, respectively (20)]; (5) limitation of alcohol consumption [1.9/0.6 $\mathrm{mmHg}$ of systolic and diastolic BP reduction, respectively (21)]; (6) smoking cessation (22) (Table 2). The highlighting of lifestyle measures by the ESH guidelines is commendable, but should be interpreted as appropriate counseling given to patients. Nonetheless, strict application of this definition implies that subjects non-compliant with these directions, just like those non-compliant to medical treatment, would not meet the criteria for $\mathrm{RH}$.

The three major international societies $(13,14,16)$ do not specify the drugs in their definition of RH, while the British NICE dictates the classes of medications, which are an angiotensin converting enzyme inhibitor (ACE-I) or an angiotensin II receptor blocker (ARB), a calcium channel blocker (CCB), and a diuretic 


\section{Table 1 | Definitions of resistant hypertension according to major scientific societies.}

\begin{tabular}{|c|c|}
\hline $\begin{array}{l}\text { Society/year/ } \\
\text { reference }\end{array}$ & Definition \\
\hline VC & ood pressure above goal \\
\hline & $\begin{array}{l}\text { Adhesion to full doses of an appropriate three-drug } \\
\text { regimen } \\
\text { One of the three agents is necessarily a diuretic }\end{array}$ \\
\hline $\begin{array}{l}\text { AHA Scientific } \\
\text { Statement } 2008 \\
\text { (13) }\end{array}$ & $\begin{array}{l}\text { Blood pressure above goal in spite of the concurrent } \\
\text { use of three antihypertensive agents of different } \\
\text { classes } \\
\text { One of the three agents ideally should be a diuretic } \\
\text { Patients whose blood pressure is controlled but } \\
\text { requires four or more medications }\end{array}$ \\
\hline $\begin{array}{l}\text { NICE Guidelines } \\
2011 \text { (15) }\end{array}$ & $\begin{array}{l}\text { Blood pressure higher than } 140 / 90 \mathrm{mmHg} \text { after } \\
\text { treatment with optimal or best tolerated doses of } \\
\text { drugs } \\
\text { Drug therapy including an ACE inhibitor or an ARB } \\
\text { combined with a calcium channel blocker and a } \\
\text { diuretic }\end{array}$ \\
\hline $\begin{array}{l}\text { ESH/ESC } \\
\text { Guidelines } 2013 \\
\text { (14) }\end{array}$ & $\begin{array}{l}\text { Systolic and diastolic blood pressure values above } 140 \\
\text { and } 90 \mathrm{mmHg} \text {, respectively } \\
\text { Therapeutic strategy including lifestyle measures } \\
\text { Drug therapy including a diuretic and two other } \\
\text { antihypertensive drugs belonging to different classes } \\
\text { at adequate doses }\end{array}$ \\
\hline
\end{tabular}

Table 2 | Lifestyle changes associated to a BP decrease.

Salt restriction $(6 / 3 \mathrm{mmHg}$ up to $20 / 10 \mathrm{mmHg}$ of systolic and diastolic BP reduction, respectively)

Diet low on saturated fat/cholesterol and high on vegetables, fruits, fish diet $(5 / 3 \mathrm{mmHg}$ of systolic and diastolic BP reduction, respectively)

Weight reduction (1 $\mathrm{mmHg}$ of $\mathrm{BP}$ decrease per kilogram of weight loss)

Aerobic physical exercise $(7 / 5 \mathrm{mmHg}$ of systolic and diastolic BP reduction, respectively)

Limitation of alcohol consumption $(1.9 / 0.6 \mathrm{mmHg}$ of systolic and diastolic BP reduction, respectively)

Smoking cessation

(15). Messerli et al. proposed an even more restrictive definition: a systolic BP of $160 \mathrm{mmHg}$ or higher despite treatment with a full dose of a renin-angiotensin-aldosterone system (RAAS) blocker (either an ACE-I, an ARB, or a renin inhibitor), a CCB (either dihydropyridine or non-dihydropyridine), a diuretic (preferentially chlorthalidone), and, if tolerated, a mineralocorticoid receptor (MR) antagonist (MRA) (spironolactone or eplerenone) (23).

Such more strict criteria to define RH could be useful but carry some limitations: patients not having BP at goal despite being treated with more than three drugs, but with intolerance or contraindication to a class of drugs, such as, for example, a RAAS blocker in subjects with bilateral renal artery stenosis, or a CCB in those with low ejection fraction heart failure, would not meet the definition for RH. Such incorrect classification of these patients, can imply that they will not be perceived as being at high-risk, thus affecting their management and prognosis and impairing data comparability of cohort studies or clinical trials using different definitions.

In summary, there is an urgent need to homogenize the definitions of RH by including also the patients intolerant to the drugs suggested by guidelines and experts $(15,23)$ if in need of more than three drugs and with BP above goal.

\section{RESISTANT HYPERTENSION: RELEVANCE OF THE ISSUE}

Data from large clinical trials of anti-hypertensive therapy suggest that the prevalence of $\mathrm{RH}$ can be as high as 35\% (2429) (Table 3). These numbers are probably overestimated since patients enrolled in these trials entail selected cohorts with risk profile and comorbidities higher than the ordinary hypertensive population.

Observational studies likely provide a more genuine estimate of the actual figures involved and show that RH involves $10-20 \%$ of the general population of hypertensive patients (30). However, some drawbacks mandate caution in interpreting these data. For instance, in a United States cohort, after exclusion of non-adherent subjects, who can entail $37 \%$ of patients with uncontrolled hypertension (8), a rate of RH of $12.8 \%$ was reported. However, the assumption of diuretics, which for most guidelines represents a condicio sine qua non-for the diagnosis, was neglected (31). Moreover, patients with white-coat syndrome, who can be up to $40 \%$ of patients with "resistant hypertension" (4), were not excluded. In another US study, Daugherty et al. found that the prevalence of RH was $16.2 \%$, but the same biases existed (32). Finally, a Spanish study that estimated a prevalence of RH of $8.9 \%$ and devoted proper attention to exclude those with the white-coat effect did not assess drug adherence (4). Of interest, two studies looking specifically at the rate of $\mathrm{RH}$ provided quite different estimates. According to Pierdomenico et al., who defined $\mathrm{RH}$ as office BP $\geq 140$ or $\geq 90 \mathrm{mmHg}$ for systolic and diastolic, respectively, at least at two visits while on triple therapy, the prevalence would be $18 \%$ (5). By contrast, the Spanish ambulatory blood pressure monitoring ( $\mathrm{ABPM})$ Registry that in similarly treated patients based the definition on identical criteria for clinical BP but also used ABPM daytime $\mathrm{BP} \geq 130$ or $\geq 80 \mathrm{mmHg}$ for systolic and diastolic, respectively, reported a prevalence of $7.6 \%$ (4). Hence, it is altogether evident that ABPM is necessary to pinpoint those with clinic high $\mathrm{BP}$ that is due to the white-coat phenomenon.

The attention that $\mathrm{RH}$ is receiving mainly derives from the evidence that it associates not only with subclinical target organ damage, such as left ventricular hypertrophy $(11,33,34)$, microalbuminuria $(31,33-36)$, impaired renal function $(31,34)$, and vascular involvement revealed by carotid intima media thickening (11) exceeding that of patients with well controlled BP, but also with a worse prognosis. These subjects are in fact exposed to an excess risk of stroke, myocardial infarction, congestive heart failure, and chronic kidney disease $(12,37)$. Indeed, while studies comparing resistant and non-resistant hypertensives consistently showed a higher risk in former, up to $50 \%$ (hazard ratio 1.47, 95\% confidence interval 1.33-1.62) of cardiovascular events and renal events $(5,32,38)$, the estimates of this excess risk are imprecisely 
Table 3 | Resistant hypertension prevalence in randomized controlled trials.

\begin{tabular}{|c|c|c|c|c|}
\hline Study & Pts $\left(n^{\circ}\right)$ & $\begin{array}{l}\text { Hypertensive Pts } \\
\text { characteristics }\end{array}$ & Definition RH & $\begin{array}{l}\text { Prevalence } \\
\text { of RH (\%) }\end{array}$ \\
\hline ALLHAT & 14,684 & $\begin{array}{l}\geq 55 \mathrm{y} / \mathrm{o} \\
\text { stage } 1 \text { or } 2 \mathrm{HTN} \\
\geq 1 \mathrm{RF} \text { for } \mathrm{CAD}\end{array}$ & Pts on $\geq 3$ drug classes $B P \geq 140 / 90 \mathrm{mmHg}$ OR pts $\geq 4$ drug classes & 12.7 \\
\hline ASCOT-BPLA & 19,257 & $\begin{array}{l}40-79 y / 0 \\
\geq 3 \mathrm{CV} R F\end{array}$ & Pts on $\geq 3$ drug classes $B P \geq 140 / 90 \mathrm{mmHg}$ OR pts $\geq 4$ drug classes & 48.5 \\
\hline LIFE & 9,222 & $\begin{array}{l}55-80 \text { y/o } \\
\text { EKG signs LVH }\end{array}$ & Pts on $\geq 3$ drug classes (HCT included) $B P \geq 140 / 90 \mathrm{mmHg}$ & 53.9 \\
\hline CONVINCE & 16,476 & $\begin{array}{l}\geq 55 \mathrm{y} / \mathrm{o} \\
\geq 1 \mathrm{CV} \text { RF }\end{array}$ & Pts on $\geq 3$ drug classes (HCT included) $\mathrm{BP} \geq 140 / 90 \mathrm{mmHg}$ & 34.3 \\
\hline
\end{tabular}

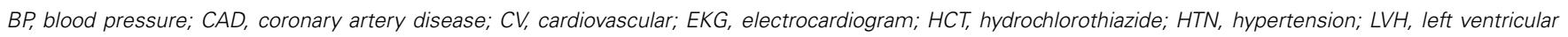
hypertrophy; Pts, patients; $R$ F, risk factor; $R H$, resistant hypertension; y/o, years old.

known. For example, in a survey of more than 50,000 hypertensive patients with at least three cardiovascular risk factors the detrimental effect was lower than expected, with an excess risk for cardiovascular events (hazard ratio 1.18, 95\% confidence interval 1.10-1.26), especially non-fatal stroke (hazard ratio $1.26,95 \%$ confidence interval 1.10-1.45) and congestive heart failure (hazard ratio $1.36,95 \%$ confidence interval $1.23-1.51$ ) in patients with RH compared to non-resistant hypertensives (39).

Thus, even though the evidence collectively indicates that $\mathrm{RH}$ implies an excess risk of cardiovascular events, the extent of this increased risk varies widely, likely reflecting the variable definitions of RH across studies.

\section{PATHOGENESIS OF RESISTANT HYPERTENSION AND POTENTIAL BENEFITS OF MINERALOCORTICOID RECEPTOR ANTAGONISTS}

In patients with uncontrolled BP pseudo-resistance must be excluded beforehand. The latter can be secondary to: (1) poor office BP measurement technique, (2) "white-coat" effect, which encompasses up to $40 \%$ of patients with uncontrolled BP (4), (3) non-adherence to the prescribed therapy [30-40\% of subjects ( 7 , $8)$ ], or (4) a suboptimal anti-hypertensive regimen, owed to inappropriate drug associations or therapeutic inertia (40-42). Only after exclusion of pseudo-resistance and of secondary hypertension patients can be labeled as having $\mathrm{RH}$, whose most common causes are: excessive salt intake and obesity. In our view, the diagnosis of RH should be regarded as a provisional classification of the patient and by no means a long-time definition for the following reason: many patients with $\mathrm{RH}$ if properly investigated are found to be affected by secondary forms of high BP.

Several substances or pharmacological agents can induce hypertension or reduce the efficacy of anti-hypertensive therapies and have been associated to $\mathrm{RH}$ (10). A special mention among the pharmacological agents pertains to the non-steroidal antiinflammatory, oestro-progestinic, steroid, and immunosuppressive drugs, because of their widespread use. Likewise, due to their increasing diffusion a careful history on abuse substances, such as cocaine and amphetamines, as well as alcohol and coffee, should be elicited.

Compared to uncomplicated well controlled hypertensive patients those with uncontrolled BP display a higher prevalence of secondary hypertension, due to primary aldosteronism (7-20\%) $(43,44)$, renal artery stenosis $(2-24 \%)(45,46)$, and chronic kidney diseases $(30-40 \%)(31,34,36,47)$, with rates varying across studies because of the different selection criteria, cohorts, and diagnostic work-up exploited.

Primary aldosteronism is the most frequent cause of secondary hypertension $(48,49)$ in newly diagnosed referred consecutive hypertensive patients and when surgically non-curable forms are present its most appropriate treatment are MRAs. In the PAPY study, including 1,125 consecutive hypertensive patients enrolled at 18 referral centers throughout Italy, who were screened while either on pharmacological wash-out or on CCB and/or doxazosin treatment, the prevalence of primary hyperaldosteronism was 11.2 and $43 \%$ of these cases had an aldosterone-producing adenoma (APA) (49). Of note, only $48 \%$ of patients with APA and $17 \%$ of those with idiopathic hyperaldosteronism had hypokalemia at clinical presentation. Moreover, even though the prevalence of primary aldosteronism increased with the severity of hypertension most cases were seen in stage I and stage II hypertension. These evidences contradict the fallacious perception that a diagnosis of primary aldosteronism should be pursued only in patients with hypokalemia (49). Because of the misconception that primary aldosteronism is a disease of hypertensive patients with hypokalemia and severe/resistant hypertension it goes mostly unnoticed (49). Furthermore, the diagnostic work-up bears more difficulties in patients on multiple drugs, most of which affect the RAAS (50).

In addition to primary aldosteronism, most patients with $\mathrm{RH}$ develop a secondary aldosteronism triggered by a diuretic-induced sodium depletion, which activates the RAAS, similarly to what happens with sodium restriction $(17,51)$. In this context, it is 
worth noting how MRAs can effectively counteract this effect and improve BP control. Similarly, long-term use of RAAS inhibitors (ACE-I and ARB) is known to be associated with angiotensin II increase and ensuing aldosterone production, which can contribute to resistance to the anti-hypertensive therapy. In fact, whereas the acute effect of RAAS inhibitors is a decrease of aldosterone, in the long run aldosterone can increase to levels even higher than pretreatment $(52,53)$, as well documented in a relevant proportion (10-53\%) of the patients with heart failure or chronic kidney disease on protracted ACE-I or ARB treatment (54).

The MR, besides its well-known effects in the kidney, has extra-renal actions that could affect BP regulation (55), including activation of the sympathetic nervous system (56), endothelial dysfunction (57), and vasoconstriction (58) through stimulation of the human vascular smooth muscle cells (59). Moreover, blacks have lower plasma renin activity (PRA) and plasma aldosterone levels than whites, but their BP is directly associated with the plasma aldosterone concentration and increases with 9- $\alpha$ fludrocortisone administration, an effect that does not occur in whites (60). Hence, collectively these observations suggest differences in the individual sensitivity of the vasculature to MR activation (61).

Finally, the activity of the MR-dependent pathways can be triggered without increases of plasma aldosterone levels through mechanisms different from raised receptor sensitivity, such as increased receptor expression or stimulation by other ligands [reviewed in Ref. (62)], as for example angiotensin II (63-65) or cortisol (62).

Excessive dietary salt intake with ensuing volume overload is a well recognized risk factor for $\mathrm{RH}(66,67)$ owing to its pressor effect and its blunting of the BP-lowering action of antihypertensive agents. According to the available studies $90 \%$ of the patients with $\mathrm{RH}$ have some degree of plasma volume expansion (68) and raised levels of brain-type and atrial natriuretic peptides (69). The same studies also showed high levels of plasma aldosterone and aldosterone-renin ratio, and low PRA, which could be explained either by the high prevalence of undetected primary aldosteronism $(43,44)$ or by the secondary aldosteronism due to diuretic treatment (69). Two different approaches relying on this premises proved to be efficacious in RH patients: (1) the estimation of body volume expansion by measurement of thoracic bioimpedance as a guide to up-titrate diuretics (70); (2) the sequential blockade of the nephron by means of stepped addition of four low-dose diuretics, spironolactone among others, to antagonize the sodium and water reabsorption along the nephron (51).

Obesity $(50-55 \%)$ is common in patients with $\mathrm{RH}(4,34)$ and is associated to suboptimal $\mathrm{BP}$ control as demonstrated by the HYDRA study (71). The underlying pathophysiology of the BP elevation in obese patients entails a combination of sodium retention, activation of the sympathetic nervous system (72), sleep-related breathing disorders, and relative hyperaldosteronism with ensuing volume expansion (73).

Patients with RH bear an extensive, up to $70 \%$, prevalence of obstructive sleep apnea (OSA) $(45,74-76)$, which is increasingly recognized as an important determinant of uncontrolled hypertension. The improvements of BP control in affected subjects undergoing efficacious treatment of OSA with continuous positive air pressure ventilation support a causal link between these conditions $(77,78)$. The putative pathogenesis is possibly ascribed to the increased upper airway resistance and intermittent hypoxia, which activate the sympathetic nervous system and the RAAS, as suggested by the association of its severity with plasma aldosterone levels (76) and by the improvement of OSA patients on spironolactone treatment (79).

Taken together these evidences reveal the complexity of the pathogenesis of $\mathrm{RH}$ and a key role for the MR in it, thus suggesting the relevant role of MRA therapy in this field.

\section{CURRENT THERAPIES FOR RESISTANT HYPERTENSION}

Adherence to a low-sodium diet ranks first among the lifestyle measures to be recommended to all hypertensive patients because it is highly effective in decreasing both systolic and diastolic BP (4-7 and $1-3 \mathrm{mmHg}$, respectively) as recently demonstrated (47, 80, 81) with effects even more striking in patients with $\mathrm{RH}$ (67). Moreover, regular isotonic exercise should be included in the therapeutic approach to $\mathrm{RH}$ in that it is able to decrease $\mathrm{BP}$ even in subjects with low responsiveness to medical treatment (82).

Another point that has to be highlighted and pursued in $\mathrm{RH}$ is that drug association therapy is typically more effective than increasing the dose of each medication. This was clearly evidenced in a meta-analysis of 354 randomized placebo-controlled trials showing that doubling the anti-hypertensive agent dosage was less effective in lowering systolic and diastolic BP than combination therapy [ 2 and $1 \mathrm{mmHg}$ vs. $6-7$ and 3-4 $\mathrm{mmHg}$, respectively (83)]. These results were later confirmed by a subsequent meta-analysis (84) and in the OSCAR trial examining an intensified monotherapy regimen with a high-dose ARB (40 mg olmesartan) and an association approach with a low-dose ARB (20 mg olmesartan) plus a dihydropiridinic CCB (amlodipine or azelnidipine) (85). Despite a similar decrease of BP in the two treatment arms, combination therapy reduced the incidence of cardiovascular events and death in high-risk patients with a history of cardiovascular morbidity at baseline.

Among diuretics, chlorthalidone, a long-acting thiazide-like diuretic, is held to be more potent than hydrochlorothiazide in lowering BP (86) and therefore should be preferred, according to Messerli, over the latter, which at its usual dose of $12.5-25 \mathrm{mg}$ is inferior to other anti-hypertensive agents $(87,88)$. However, due to its long half-life $(50 \mathrm{~h})$, which exposes to a carry-over effect with daily assumption, it confers a higher risk of hypokalemia. The chlorthalidone-induced hypokalemia was in fact suggested to be a sign of undetected primary aldosteronism (89).

The ESH/ESC guidelines suggest that patients with RH and persistently elevated BP values despite medical treatment optimization should be considered for invasive procedures such as carotid baroreceptor stimulation and renal denervation (see Table 4). The former seems a promising technique, as evidenced by the Rheos pivotal trial. This relatively large randomized controlled trial showed a borderline significant greater SBP reduction in the treatment arm compared to the placebo group (16 vs. $9 \mathrm{mmHg}$, respectively, $p=0.08$ ) (90). Regarding renal denervation, the high expectations generated by the SYMPLICITY HTN-1 (91) and 2 (92) trials were attenuated by the results of the SIMPLICITY HTN-3 trial, which could not demonstrate an advantage of the procedure compared to sham controls in patients with $\mathrm{RH}$ in part 
Table 4 | ESH/ESC guidelines on resistant hypertension invasive treatment.

\begin{tabular}{lcc}
\hline Recommendation & Class & Level \\
\hline $\begin{array}{l}\text { Invasive procedures may be considered in } \mathrm{RH} \\
\text { patients if drug treatment is ineffective }\end{array}$ & $\mathrm{Ilb}$ & $\mathrm{C}$ \\
Invasive procedures should be carried out by & । & $\mathrm{C}$ \\
experienced operators; diagnosis and follow-up & & \\
should be restricted to hypertension centers & & $\mathrm{C}$ \\
Invasive procedures should be considered only in \\
truly $\mathrm{RH}$ patients with clinic SBD $\geq 160 \mathrm{mmHg}$ \\
and $\mathrm{DBP} \geq 110 \mathrm{mmHg}$ and confirmed at ABPM
\end{tabular}

$A B P M$, ambulatory blood pressure monitoring; $D B P$, diastolic blood pressure; $R H$, resistant hypertension; SBP, systolic blood pressure.

due to the larger than expected BP fall in the sham group, but, interestingly enough, also for the higher rate of treatment with MRAs in this trial than in the previous ones (93).

In conclusion, although in the definition of RH only the generic term "diuretic" is mentioned, by no means all diuretics are equal and a careful choice of the agent along with appropriate uptitration of the dose(s) are key for bringing BP under control. Among diuretics, MRAs deserve a special place for the multitude of potential benefits they provide, so that some experts advocate their use as a fourth line add-on drug in patients with $\mathrm{RH}(23,94)$.

\section{EVIDENCES THAT MINERALOCORTICOID RECEPTOR ANTAGONISTS ARE EFFICACIOUS IN RESISTANT HYPERTENSION}

Treatment of hypertension with MRAs was introduced almost 40 years ago (95-97). Spironolactone proved to be as effective as propranolol (95) and chlorthalidone (97), and remained efficacious as an add-on therapy in patients already receiving a diuretic (98), probably due to the blunting of the aldosterone breakthrough effect. Eplerenone was developed in an attempt to overcome the adverse effects of MRAs, including erectile dysfunction and gynecomastia, which depends on their anti-androgenic effects (99-101). This compound was suggested to be more selective (102) and at least as effective as losartan (103) or even superior to the former in patients with low-renin hypertension (104) and in those of African-American descent (103). Eplerenone was also shown to be as effective as enalapril $(105,106)$ and amlodipine (107) as an add-on therapy to ACE-I or ARB monotherapy (108). However, it is shorter acting and less potent than spironolactone, canrenone, and potassium canreonate. Moreover, when used at doses equipotent as spironolactone on BP, it was found to cause estrogen-like effects. Of note, the EVALUATE study, a multicenter, randomized, double blind clinical trial of patients with hypertension and stage 2 and 3 chronic kidney disease, showed that both $\mathrm{BP}$ and microalbuminuria were significantly lower over 52 weeks of follow-up in patients assigned to a low-dose eplerenone once a day than in those receiving placebo, both on top of treatment with an ACE-I or an ARB. No hyperkalemia, gynecomastia, or erectile dysfunction were observed with such a low-dose of this MRA (109).
Several authors have highlighted the value of MRAs in patients with RH by virtue of cohort studies (110-116) [reviewed by Ref. $(117,118)]$ and of placebo-controlled clinical trials (51, 119-122), which are held to provide harder evidences, as outlined in the following paragraphs (Table 5).

The first placebo-controlled trial testing the efficacy of MRAs in RH was the ASPIRANT, which included 117 patients randomized to $25 \mathrm{mg}$ of spironolactone or placebo and assessed with $24 \mathrm{~h}$ ABPM (119). After 8 weeks of treatment the MRA decreased mean daytime systolic BP of $5 \mathrm{mmHg}(95 \% \mathrm{CI} 10-0.8 \mathrm{mmHg})$, e.g., the primary endpoint, and microalbuminuria of $4.4 \mathrm{mg} /$ day, while it did not reduce mean daytime diastolic BP (1 mmHg, 95\% CI -4$2 \mathrm{mmHg}$ ). This trial was stopped prematurely after reaching the primary endpoint in an ad interim analysis. However, $24 \%$ of the patients enrolled were found to have primary aldosteronism at further evaluation, which most likely contributed to the favorable results of the study. Moreover, patients with glomerular filtration rate lower than $40 \mathrm{ml} / \mathrm{min}$ were excluded from the ASPIRANT trial owing to the potential risks of hyperkalemia.

Therefore, a randomized placebo-controlled trial was performed by Abolghasmi et al. to prove the efficacy of MRA therapy in chronic kidney disease patients (120). The authors randomized 41 patients with chronic kidney disease (glomerular filtration rate between 50 and $25 \mathrm{ml} / \mathrm{min}$ ) to $25-50 \mathrm{mg}$ /day of spironolactone or placebo and found that at 6 weeks the MRA decreased systolic and diastolic BP of 33 and $13 \mathrm{mmHg}$, respectively, whereas placebo did not affect BP. It is worth highlighting that patients with secondary hypertension other than chronic kidney disease were excluded from the study and that only one out of 19 cases receiving MRA treatment developed hyperkalemia (>5.5 mmol/l). Despite the relevance of these results some drawbacks ought to be mentioned, such as the use of a subjective way to assess therapeutic efficacy of MRA like office BP in lieu of the more objective ABPM and the lack of details on randomization and blinding procedures.

To test the non-inferiority of a sequential nephron blockade strategy (by means of the sequential addition of spironolactone, furosemide, and amiloride) vs. a sequential renin-angiotensin system blockade (by virtue of add-on ramipril and bisoprolol at increasing doses) Bobrie et al. randomized 167 patients with $\mathrm{RH}$, treated with irbesartan $300 \mathrm{mg}$ /day, hydrochlorothiazide $12.5 \mathrm{mg} /$ day, and amlodipine $5 \mathrm{mg} /$ day (51). The trial demonstrated that the sequential nephron blockade was more efficacious than the renin-angiotensin system blockade at decreasing BP in these patients as assessed by ABPM. Moreover, it showed a significant decrease in systolic and diastolic BP in patients treated with spironolactone $25 \mathrm{mg} /$ day as compared to ramipril $5 \mathrm{mg} /$ day. These results are potentially important for $\mathrm{RH}$ patients but carry two main limitations: (i) the trial was not specifically designed to test the efficacy of spironolactone; (ii) when either spironolactone or ramipril were added, patients were not receiving a maximal dose of diuretic and CCB and therefore, strictly speaking, they did not meet the RH definition.

To test the efficacy in lowering mean sitting systolic BP of a new compound, the aldosterone synthase inhibitor LCI699, Karns et al. randomized 155 patients to receive a placebo or the active drug (122). The study failed his primary endpoint in that it could not demonstrate a significant decrease of BP with the aldosterone 
Table 5 | Randomized controlled trials comparing mineralocorticoid receptor antagonists vs. placebo in resistant hypertension patients.

\begin{tabular}{|c|c|c|c|c|c|c|c|c|}
\hline Study & $\begin{array}{l}\text { Pts } \\
\left(n^{\circ}\right)\end{array}$ & $\begin{array}{l}\text { Pts } \\
\text { characteristics }\end{array}$ & End points & MRA & $\begin{array}{l}\text { Dose } \\
\text { mg/day }\end{array}$ & Control & $\begin{array}{l}\text { Follow up } \\
\text { weeks }\end{array}$ & Results \\
\hline $\begin{array}{l}\text { Vaclavík } \\
\text { et al. }\end{array}$ & 117 & $\mathrm{RH}$ pts & $\begin{array}{l}\text { Decrease of daytime SBP and } \\
\text { DBP on ABPM }\end{array}$ & Spironolactone & 25 & Placebo & 8 & $\begin{array}{l}5.4 \mathrm{mmHg} \text { decrease of } \\
\text { daytime SBP }\end{array}$ \\
\hline $\begin{array}{l}\text { Abolghasmi } \\
\text { et al. }\end{array}$ & 41 & $\begin{array}{l}\text { RH pts with } \\
\text { CKD }\end{array}$ & $\mathrm{n} / \mathrm{a}$ & Spironolactone & $25-50$ & Placebo & 12 & $\begin{array}{l}\text { 30/8 mmHg SBP and DBP } \\
\text { decrease (office BP) }\end{array}$ \\
\hline $\begin{array}{l}\text { Oxlund } \\
\text { et al. }\end{array}$ & 119 & $\begin{array}{l}\text { RH pts with } \\
\text { type } 2 \text { DM }\end{array}$ & $\begin{array}{l}\text { Reduction of daytime SBP } \\
\text { and DBP at ABPM }\end{array}$ & Spironolactone & 25 & Placebo & 16 & $\begin{array}{l}\text { 8.9/3.7 } \mathrm{mmHg} \text { daytime SBP } \\
\text { and DBP decrease (ABPM) }\end{array}$ \\
\hline $\begin{array}{l}\text { Karns } \\
\text { et al. }\end{array}$ & 155 & $\mathrm{RH}$ pts & $\begin{array}{l}\text { Mean sitting SBP of } \mathrm{LCl} \text { vs. } \\
\text { placebo }\end{array}$ & Eplerenone & 100 & $\begin{array}{l}\text { LCl699, } \\
\text { placebo }\end{array}$ & 8 & $\begin{array}{l}\text { No difference LCl699 vs. } \\
\text { placebo; decrease of } \\
\text { 14.7/9.4 mmHg, SBP and } \\
\text { DBP, with eplerenone (ABPM) }\end{array}$ \\
\hline
\end{tabular}

ABPM, ambulatory blood pressure monitoring; CKD, chronic kidney disease; DBP, diastolic blood pressure; DM, diabetes mellitus; n/a, not available; Pts, patients; $R H$, resistant hypertension; SBP, systolic blood pressure; SNB, sequential nephron blockade; SRASB, sequential renin-angiotensin system blockade; $w$, weeks.

synthase inhibitor at various doses compared to placebo. However, interestingly enough, it showed that after 8 weeks eplerenone induced a significant decrease of systolic and diastolic BP compared to placebo (14-15 and 9-11 mmHg, respectively) as assessed at ABPM. Despite not being originally designed to compare MRA therapy with placebo, this study is important in that it extends to the whole MRA class the efficacy in RH.

Finally, Oxlund et al. tested in a randomized placebo-controlled trial the effect of a MRA in reducing BP at ABPM in $119 \mathrm{RH}$ patients with type two diabetes mellitus (121). Using ABPM, the study showed that spironolactone at a mean dose of $35 \mathrm{mg} /$ day significantly reduced systolic and diastolic BP by 9 and $4 \mathrm{mmHg}$, respectively. The MRA treatment was three times more efficacious than placebo both in lowering BP values at target and in decreasing microalbuminuria.

In summary, both observational studies and randomized trials support the conclusion that MRAs are effective in patients with RH. It has to be acknowledged, however, that these trials had few drawbacks including small sample size (51, 119-122), absence of a systematic exclusion of patients with secondary hypertension (119-122), white-coat hypertension (120, 122), and treatment non-adherence (51, 119-122), and endpoints were often not specifically focused to demonstrate the effect MRAs (51, 122). Despite these limitations, the evidence for efficacy of the MRA in patients with RH now appears to be compelling thus strengthening the proposal both of including MRAs as a cornerstone therapy in patients with difficult-to-control hypertension and the need of lack of response to a MRA as a condicio sine qua non for the definition of RH (Figure 1).

\section{PREDICTORS OF MINERALOCORTICOID RECEPTOR ANTAGONISTS EFFICACY}

The main issue in dealing with $\mathrm{RH}$ is how to select the appropriate treatment for most patients, which implies finding some predictors of their efficacy.
In treatment-naive hypertensive patients (123) and in those on multiple drugs $(112,124)$ serum potassium values below 4.0 $4.5 \mathrm{mmol} / \mathrm{l}$ were reported to forecast MRAs efficacy. However, even though low serum potassium could indicate patients with underlying primary or secondary hyperaldosteronism, not all the literature concur with this finding (119).

To predict the response to MRA almost 40 years ago Karlberg et al. observed that spironolactone was more effective in previously untreated patients with low-renin $($ PRA $<1.0 \mathrm{ng} / \mathrm{ml} / \mathrm{h}$ ) essential hypertension (95), a finding subsequently confirmed (123) and extended to patients with $\mathrm{RH}$ tested while on antihypertensive treatment (119). A correlation was also reported between the aldosterone-renin ratio and MRA efficacy in patients undergoing MRA monotherapy (123) and with RH (119). However, other studies including untreated stage 1 or 2 hypertensives (105), or enrolling subjects with low-renin hypertension (PRA $<1.0 \mathrm{ng} / \mathrm{ml} / \mathrm{h})$ (104), patients undergoing treatment with eplerenone as an add-on drug to ACE-I or ARB (125), and patients with multi-drug therapy $(126)$ or with $\mathrm{RH}(111,123)$ dispute these findings.

In conclusion, it remains still controversial if renin, aldosterone, and the aldosterone-renin ratio can predict the $\mathrm{BP}$ response to MRA in patients already on anti-hypertensive treatment $(104,105,111,119,123,125,126)$. Most likely this is because these measurements are deeply biased by the concomitant anti-hypertensive treatment (125). In keeping with this interpretation, data were more consistent in treatment-naïve patients where these measurements seem to have a role $(95,123)$. The use of serum potassium level as a predictor of efficacy could be more reliable; however, its usefulness can be affected by the cut-off value of baseline serum potassium chosen in the different studies as a threshold for up-titrating the MRA treatment (94). In fact, adequate dosing of the MRA is a crucial step for increasing the rate of patients' response to this treatment (55). 


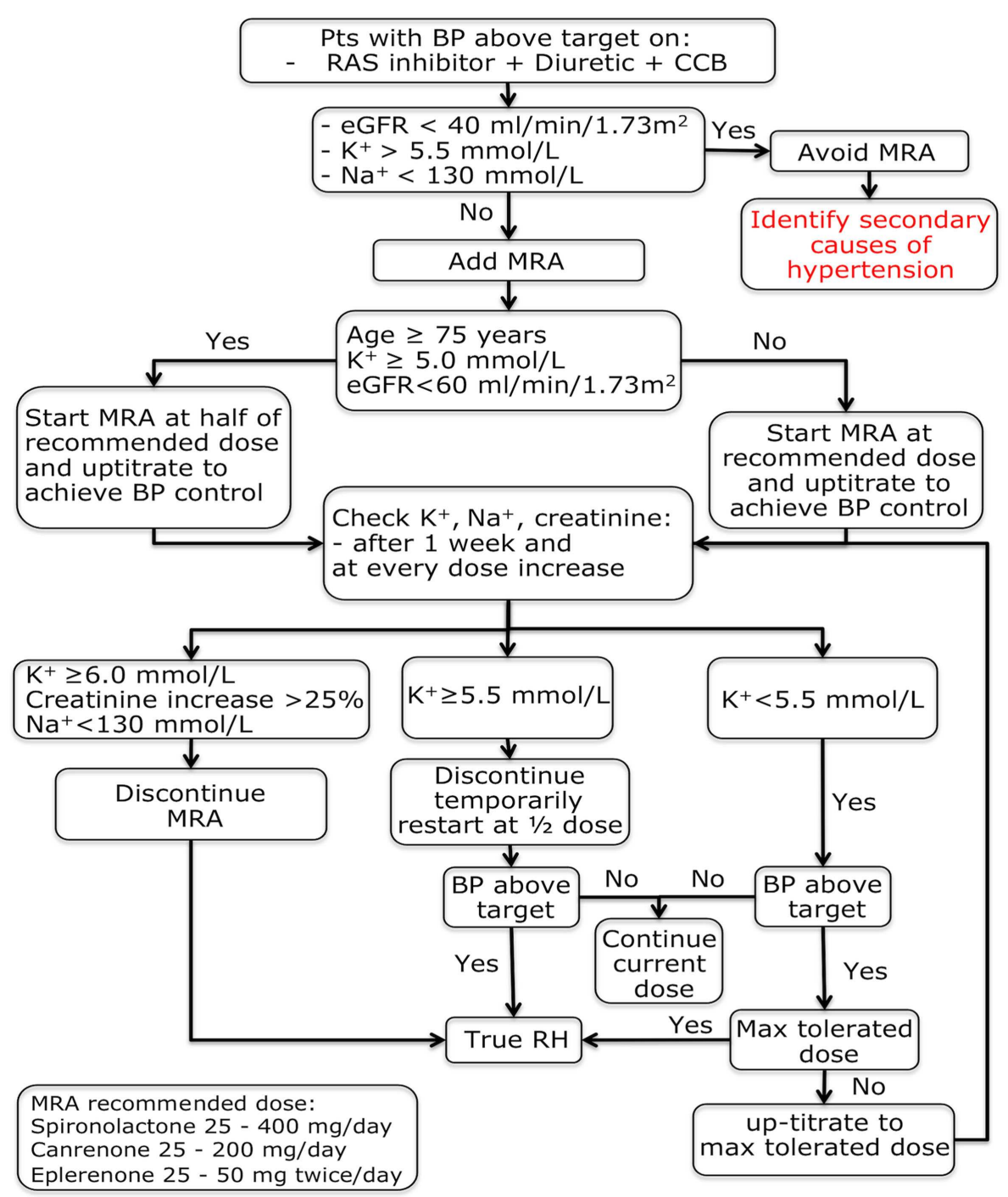

FIGURE 1 | Mineralocorticoid receptor antagonists treatment algorithm in patients with a provisional resistant hypertension diagnosis. $\mathrm{BP}$, blood pressure; eGFR, estimated glomerular filtration rate; $\mathrm{K}^{+}$, potassium; MRA, mineralocorticoid receptor antagonist; $\mathrm{Na}^{+}$, sodium; $\mathrm{RH}$, resistant hypertension.

\section{CONTRAINDICATIONS TO MINERALOCORTICOID RECEPTOR ANTAGONISTS THERAPY}

Despite being usually well-tolerated MRAs should be cautiously prescribed to special populations. Pregnant and breast-feeding women should avoid MRAs, which cross the placenta, especially in the first trimester, and enter the breast milk, due to their antiandrogenic effect. Monitoring of side effects should be carried out in male subjects, who can complain of erectile dysfunction and gynecomastia.

Due to a higher probability of side effects elderly $(\geq 75$ years) and chronic renal disease (glomerular filtration rate $<60 \mathrm{ml} / \mathrm{min} / 1.73 \mathrm{~m}^{2}$ ) patients should be prescribed MRAs judiciously. We suggest to halve the starting dose of the drug and to check renal function, serum potassium, and sodium levels after 1 week and after every dose increase. Using these precautions the prescription of MRAs appears safe as demonstrated by trials conducted in patients with chronic renal insufficiency [glomerular filtration rate $\geq 25-50 \mathrm{ml} / \mathrm{min} / 1.73 \mathrm{~m}^{2}(109,120)$ ] where hyperkalemia occurred only sporadically.

Serum potassium testing is mandatory before MRA therapy prescription, in that hyperkalemia is a serious side effect of these drugs, which therefore must not be given to hyperkalemic patients. However, in normokalemic patients with regular testing these medications are safe as showed by clinical trials completed in subjects with RH (119) or chronic kidney disease (109). As a rule of thumb, it is a safe practice to avoid MRAs administration to patients with hyperkalemia $(\geq 5.5 \mathrm{mmol} / \mathrm{l})$ and to decrease its dose when at reassessment the serum potassium increases $\geq 5.5 \mathrm{mmol} / \mathrm{l}$, while discontinuing indefinitely this therapy if it increases $\geq 6.0 \mathrm{mmol} / \mathrm{l}$.

Finally, a particular mention deserves the concurrent prescription of MRAs with non-steroidal anti-inflammatory agents 
because of their extensive use. These agents reduce the antihypertensive treatment efficacy and, furthermore, induce a hyporeninemic hypoaldosteronism thus raising the risk of severe and life-threatening hyperkalemia (127).

\section{CONCLUSION}

Resistant hypertension is an increasingly recognized problem in hypertension treatment owing to its association with a worse prognosis. Based on increasing evidences demonstrating the contribution of aldosterone to its pathogenesis, few uncontrolled studies and randomized clinical trials were completed on this field and demonstrated the beneficial role of the mineralocorticoid receptor antagonists. Therefore, based on these evidences a strong recommendation should be made to advocate their use as a "must" in patients with resistant hypertension.

\section{REFERENCES}

1. Hajjar I, Kotchen TA. Trends in prevalence, awareness, treatment, and control of hypertension in the United States, 1988-2000. JAMA (2003) 290:199-206. doi:10.1001/jama.290.2.199

2. Lloyd-Jones DM, Evans JC, Larson MG, O’Donnell CJ, Roccella EJ, Levy D. Differential control of systolic and diastolic blood pressure: factors associated with lack of blood pressure control in the community. Hypertension (2000) 36:594-9. doi:10.1161/01.HYP.36.4.594

3. Weitzman D, Chodick G, Shalev V, Grossman C, Grossman E. Prevalence and factors associated with resistant hypertension in a large health maintenance organization in Israel. Hypertension (2014) 64:501-7. doi:10.1161/ HYPERTENSIONAHA.114.03718

4. de la Sierra A, Segura J, Banegas JR, Gorostidi M, de la Cruz JJ, Armario P, et al. Clinical features of 8295 patients with resistant hypertension classified on the basis of ambulatory blood pressure monitoring. Hypertension (2011) 57:898-902. doi:10.1161/HYPERTENSIONAHA.110.168948

5. Pierdomenico SD, Lapenna D, Bucci A, Di Tommaso R, Di Mascio R, Manente $\mathrm{BM}$, et al. Cardiovascular outcome in treated hypertensive patients with responder, masked, false resistant, and true resistant hypertension. Am J Hypertens (2005) 18:1422-8. doi:10.1016/j.amjhyper.2005.03.115

6. Egan BM, Zhao Y, Li J, Brzezinski WA, Todoran TM, Brook RD, et al. Prevalence of optimal treatment regimens in patients with apparent treatment-resistant hypertension based on office blood pressure in a community-based practice network. Hypertension (2013) 62:691-7. doi:10.1161/HYPERTENSIONAHA. 113.01448

7. Tomaszewski M, White C, Patel P, Masca N, Damani R, Hepworth J, et al. High rates of non-adherence to antihypertensive treatment revealed by highperformance liquid chromatography-tandem mass spectrometry (HP LCMS/MS) urine analysis. Heart (2014) 100:855-61. doi:10.1136/heartjnl-2013305063

8. Jung O, Gechter JL, Wunder C, Paulke A, Bartel C, Geiger H, et al. Resistant hypertension? Assessment of adherence by toxicological urine analysis. J Hypertens (2013) 31:766-74. doi:10.1097/HJH.0b013e32835e2286

9. Ceral J, Habrdova V, Vorisek V, Bima M, Pelouch R, Solar M. Difficult-tocontrol arterial hypertension or uncooperative patients? The assessment of serum antihypertensive drug levels to differentiate non-responsiveness from non-adherence to recommended therapy. Hypertens Res (2011) 34:87-90. doi:10.1038/hr.2010.183

10. Rossi GP, Seccia TM, Maniero C, Pessina AC. Drug-related hypertension and resistance to antihypertensive treatment: a call for action. J Hypertens (2011) 29:2295-309. doi:10.1097/HJH.0b013e32834c465d

11. Cuspidi C, Macca G, Sampieri L, Michev I, Salerno M, Fusi V, et al. High prevalence of cardiac and extracardiac target organ damage in refractory hypertension. J Hypertens (2001) 19:2063-70. doi:10.1097/00004872-200111000-00018

12. Muntner P, Davis BR, Cushman WC, Bangalore S, Calhoun DA, Pressel SL, et al. Treatment-resistant hypertension and the incidence of cardiovascular disease and end-stage renal disease: results from the antihypertensive and lipid-lowering treatment to prevent heart attack trial (ALLHAT). Hypertension (2014) 64:1012-21. doi:10.1161/HYPERTENSIONAHA.114.03850
13. Calhoun DA, Jones D, Textor S, Goff DC, Murphy TP, Toto RD, et al. Resistant hypertension: diagnosis, evaluation, and treatment. A scientific statement from the American heart Association professional education committee of the council for high blood pressure research. Hypertension (2008) 51:1403-19. doi:10.1161/HYPERTENSIONAHA.108.189141

14. Mancia G, Fagard R, Narkiewicz K, Redon J, Zanchetti A, Bohm M, et al. 2013 ESH/ESC guidelines for the management of arterial hypertension: the task force for the management of arterial hypertension of the European Society of Hypertension (ESH) and of the European Society of Cardiology (ESC). Eur Heart J (2013) 34:2159-219. doi:10.1093/eurheartj/eht151

15. Krause T, Lovibond K, Caulfield M, McCormack T, Williams B, Guideline Development Group. Management of hypertension: summary of NICE guidance. BMJ (2011) 343:d4891. doi:10.1136/bmj.d4891

16. Chobanian AV, Bakris GL, Black HR, Cushman WC, Green LA, Izzo JL, et al. Joint National Committee on prevention, detection, evaluation, and treatment of high blood pressure. National heart, lung, and blood institute, national high blood pressure education program coordinating committee. Seventh report of the Joint National Committee on prevention, detection, evaluation, and treatment of high blood pressure. Hypertension (2003) 42:1206-52. doi:10.1161/01.HYP.0000107251.49515.c2

17. Graudal NA, Hubeck-Graudal T, Jurgens G. Effects of low-sodium diet vs. high-sodium diet on blood pressure, renin, aldosterone, catecholamines, cholesterol, and triglyceride (Cochrane Review). Am J Hypertens (2012) 25:1-15. doi:10.1038/ajh.2011.210

18. Blumenthal JA, Babyak MA, Hinderliter A, Watkins LL, Craighead L, Lin PH, et al. Effects of the DASH diet alone and in combination with exercise and weight loss on blood pressure and cardiovascular biomarkers in men and women with high blood pressure: the ENCORE study. Arch Intern Med (2010) 170:126-35. doi:10.1001/archinternmed.2009.470

19. Neter JE, Stam BE, Kok FJ, Grobbee DE, Geleijnse JM. Influence of weight reduction on blood pressure: a meta-analysis of randomized controlled trials. Hypertension (2003) 42:878-84. doi:10.1161/01.HYP.0000094221.86888.AE

20. Cornelissen VA, Fagard RH. Effects of endurance training on blood pressure, blood pressure-regulating mechanisms, and cardiovascular risk factors. Hypertension (2005) 46:667-75. doi:10.1161/01.HYP.0000184225.05629.51

21. Cushman WC, Cutler JA, Hanna E, Bingham SF, Follmann D, Harford T, et al. Prevention and Treatment of Hypertension Study (PATHS): effects of an alcohol treatment program on blood pressure. Arch Intern Med (1998) 158:1197-207. doi:10.1001/archinte.158.11.1197

22. Primatesta P, Falaschetti E, Gupta S, Marmot MG, Poulter NR. Association between smoking and blood pressure: evidence from the health survey for England. Hypertension (2001) 37:187-93. doi:10.1161/01.HYP.37.2.187

23. Messerli FH, Bangalore S. Treatment-resistant hypertension: another Cinderella story. Eur Heart J (2013) 34:1175-7. doi:10.1093/eurheartj/eht028

24. ALLHAT Officers and Coordinators for the ALLHAT Collaborative Research Group. The antihypertensive and lipid-lowering treatment to prevent heart attack trial. Major outcomes in high-risk hypertensive patients randomized to angiotensin-converting enzyme inhibitor or calcium channel blocker vs diuretic: the antihypertensive and lipid-lowering treatment to prevent heart attack trial (ALLHAT). JAMA (2002) 288:2981-97. doi:10.1001/jama.288.23. 2981

25. Gupta AK, Nasothimiou EG, Chang CL, Sever PS, Dahlof B, Poulter NR, et al. Baseline predictors of resistant hypertension in the Anglo-Scandinavian cardiac outcome trial (ASCOT): a risk score to identify those at high-risk. J Hypertens (2011) 29:2004-13. doi:10.1097/HJH.0b013e32834a8a42

26. Jamerson K, Weber MA, Bakris GL, Dahlof B, Pitt B, Shi V, et al. Benazepril plus amlodipine or hydrochlorothiazide for hypertension in high-risk patients. N Engl J Med (2008) 359:2417-28. doi:10.1056/NEJMoa0806182

27. Dahlof B, Devereux RB, Kjeldsen SE, Julius S, Beevers G, de Faire U, et al. Cardiovascular morbidity and mortality in the Losartan intervention for endpoint reduction in hypertension study (LIFE): a randomised trial against atenolol. Lancet (2002) 359:995-1003. doi:10.1016/S0140-6736(02)08089-3

28. Pepine CJ, Handberg EM, Cooper-DeHoff RM, Marks RG, Kowey P, Messerli $\mathrm{FH}$, et al. A calcium antagonist vs a non-calcium antagonist hypertension treatment strategy for patients with coronary artery disease. The International Verapamil-Trandolapril Study (INVEST): a randomized controlled trial. JAMA (2003) 290:2805-16. doi:10.1001/jama.290.21.2805

29. Black HR, Elliott WJ, Grandits G, Grambsch P, Lucente T, White WB, et al. Principal results of the controlled onset verapamil investigation of cardiovascular 
end points (CONVINCE) trial. JAMA (2003) 289:2073-82. doi:10.1001/jama. 289.16.2073

30. Pimenta E, Calhoun DA. Resistant hypertension: incidence, prevalence, and prognosis. Circulation (2012) 125:1594-6. doi:10.1161/CIRCULATIONAHA. 112.097345

31. Persell SD. Prevalence of resistant hypertension in the United States, 20032008. Hypertension (2011) 57:1076-80. doi:10.1161/HYPERTENSIONAHA. 111.170308

32. Daugherty SL, Powers JD, Magid DJ, Tavel HM, Masoudi FA, Margolis KL, et al. Incidence and prognosis of resistant hypertension in hypertensive patients. Circulation (2012) 125:1635-42. doi:10.1161/CIRCULATIONAHA.111.068064

33. Muxfeldt ES, Bloch KV, Nogueira Ada R, Salles GF. True resistant hypertension: is it possible to be recognized in the office? Am J Hypertens (2005) 18:1534-40. doi:10.1016/j.amjhyper.2005.06.013

34. de la Sierra A, Banegas JR, Oliveras A, Gorostidi M, Segura J, de la Cruz $\mathrm{JJ}$, et al. Clinical differences between resistant hypertensives and patients treated and controlled with three or less drugs. J Hypertens (2012) 30:1211-6. doi:10.1097/HJH.0b013e328353634e

35. Oliveras A, Armario P, Hernandez-Del Rey R, Arroyo JA, Poch E, Larrousse M, et al. Urinary albumin excretion is associated with true resistant hypertension. J Hum Hypertens (2010) 24:27-33. doi:10.1038/jhh.2009.35

36. Oliveras A, Armario P, Martell-Claros N, Ruilope LM, de la Sierra A, Spanish Society of Hypertension-Resistant Hypertension Registry. Urinary albumin excretion is associated with nocturnal systolic blood pressure in resistant hypertensives. Hypertension (2011) 57:556-60. doi:10.1161/HYPERTENSIONAHA. 110.165563

37. Lewington S, Clarke R, Qizilbash N, Peto R, Collins R, Prospective Studies Collaboration. Age-specific relevance of usual blood pressure to vascular mortality: a meta-analysis of individual data for one million adults in 61 prospective studies. Lancet (2002) 360:1903-13. doi:10.1016/S0140-6736(02) 11911-8

38. Salles GF, Cardoso CR, Muxfeldt ES. Prognostic influence of office and ambulatory blood pressures in resistant hypertension. Arch Intern Med (2008) 168:2340-6. doi:10.1001/archinte.168.21.2340

39. Kumbhani DJ, Steg PG, Cannon CP, Eagle KA, Smith SC Jr, Crowley K, et al. Resistant hypertension: a frequent and ominous finding among hypertensive patients with atherothrombosis. Eur Heart J (2013) 34:1204-14. doi:10.1093/eurheartj/ehs368

40. Banegas JR, Segura J, Ruilope LM, Luque M, Garcia-Robles R, Campo C, et al. Blood pressure control and physician management of hypertension in hospital hypertension units in Spain. Hypertension (2004) 43:1338-44. doi:10.1161/01.HYP.0000127424.59774.84

41. Banegas JR, Lundelin K, de la Figuera M, de la Cruz JJ, Graciani A, RodriguezArtalejo F, et al. Physician perception of blood pressure control and treatment behavior in high-risk hypertensive patients: a cross-sectional study. PLoS One (2011) 6:e24569. doi:10.1371/journal.pone.0024569

42. Myat A, Redwood SR, Qureshi AC, Spertus JA, Williams B. Resistant hypertension. BMJ (2012) 345:e7473. doi:10.1136/bmj.e7473

43. Umpierrez GE, Cantey P, Smiley D, Palacio A, Temponi D, Luster K, et al. Primary aldosteronism in diabetic subjects with resistant hypertension. Diabetes Care (2007) 30:1699-703. doi:10.2337/dc07-0031

44. Sang X, Jiang Y, Wang W, Yan L, Zhao J, Peng Y, et al. Prevalence of and risk factors for primary aldosteronism among patients with resistant hypertension in China. J Hypertens (2013) 31:1465-71. doi:10.1097/HJH. 0b013e328360ddf6

45. Pedrosa RP, Drager LF, Gonzaga CC, Sousa MG, de Paula LK, Amaro AC, et al. Obstructive sleep apnea: the most common secondary cause of hypertension associated with resistant hypertension. Hypertension (2011) 58:811-7. doi:10.1161/HYPERTENSIONAHA.111.179788

46. Benjamin MM, Fazel P, Filardo G, Choi JW, Stoler RC. Prevalence of and risk factors of renal artery stenosis in patients with resistant hypertension. Am J Cardiol (2014) 113:687-90. doi:10.1016/j.amjcard.2013.10.046

47. Midgley JP, Matthew AG, Greenwood CM, Logan AG. Effect of reduced dietary sodium on blood pressure: a meta-analysis of randomized controlled trials. JAMA (1996) 275:1590-7. doi:10.1001/jama.275.20.1590

48. Calhoun DA, Nishizaka MK, Zaman MA, Thakkar RB, Weissmann P. Hyperaldosteronism among black and white subjects with resistant hypertension. Hypertension (2002) 40:892-6. doi:10.1161/01.HYP.0000040261.30455.B6
49. Rossi GP, Bernini G, Caliumi C, Desideri G, Fabris B, Ferri C, et al. A prospective study of the prevalence of primary aldosteronism in 1,125 hypertensive patients. JAm Coll Cardiol (2006) 48:2293-300. doi:10.1016/j.jacc.2006. 07.059

50. Rossi GP. A comprehensive review of the clinical aspects of primary aldosteronism. Nat Rev Endocrinol (2011) 7:485-95. doi:10.1038/nrendo.2011.76

51. Bobrie G, Frank M, Azizi M, Peyrard S, Boutouyrie P, Chatellier G, et al. Sequential nephron blockade versus sequential renin-angiotensin system blockade in resistant hypertension: a prospective, randomized, open blinded endpoint study. J Hypertens (2012) 30:1656-64. doi:10.1097/HJH. 0b013e3283551e98

52. Staessen J, Lijnen P, Fagard R, Verschueren LJ, Amery A. Rise in plasma concentration of aldosterone during long-term angiotensin II suppression. J Endocrinol (1981) 91:457-65. doi:10.1677/joe.0.0910457

53. Schjoedt KJ, Andersen S, Rossing P, Tarnow L, Parving HH. Aldosterone escape during blockade of the renin-angiotensin-aldosterone system in diabetic nephropathy is associated with enhanced decline in glomerular filtration rate. Diabetologia (2004) 47:1936-9. doi:10.1007/s00125-004-1542-0

54. Bomback AS, Klemmer PJ. The incidence and implications of aldosterone breakthrough. Nat Clin Pract Nephrol (2007) 3:486-92. doi:10.1038/ ncpneph0575

55. Levy DG, Rocha R, Funder JW. Distinguishing the antihypertensive and electrolyte effects of eplerenone. J Clin Endocrinol Metab (2004) 89:2736-40. doi:10.1210/jc.2003-032149

56. Gomez-Sanchez EP. Intracerebroventricular infusion of aldosterone induces hypertension in rats. Endocrinology (1986) 118:819-23. doi:10.1210/endo118-2-819

57. Farquharson CA, Struthers AD. Aldosterone induces acute endothelial dysfunction in vivo in humans: evidence for an aldosterone-induced vasculopathy. Clin Sci (Lond) (2002) 103:425-31.

58. Romagni P, Rossi F, Guerrini L, Quirini C, Santiemma V. Aldosterone induces contraction of the resistance arteries in man. Atherosclerosis (2003) 166:345-9. doi:10.1016/S0021-9150(02)00363-5

59. McCurley A, Pires PW, Bender SB, Aronovitz M, Zhao MJ, Metzger D, et al. Direct regulation of blood pressure by smooth muscle cell mineralocorticoid receptors. Nat Med (2012) 18:1429-33. doi:10.1038/nm.2891

60. Tu W, Eckert GJ, Hannon TS, Liu H, Pratt LM, Wagner MA, et al. Racial differences in sensitivity of blood pressure to aldosterone. Hypertension (2014) 63:1212-8. doi:10.1161/HYPERTENSIONAHA.113.02989

61. Funder JW. Sensitivity to aldosterone: plasma levels are not the full story. Hypertension (2014) 63:1168-70. doi:10.1161/HYPERTENSIONAHA.114.03127

62. Shibata H, Itoh H. Mineralocorticoid receptor-associated hypertension and its organ damage: clinical relevance for resistant hypertension. Am J Hypertens (2012) 25:514-23. doi:10.1038/ajh.2011.245

63. AbdAlla S, Lother H, Quitterer U. AT1-receptor heterodimers show enhanced G-protein activation and altered receptor sequestration. Nature (2000) 407:94-8. doi:10.1038/35024095

64. Yamada M, Kushibiki M, Osanai T, Tomita H, Okumura K. Vasoconstrictor effect of aldosterone via angiotensin II type 1 (AT1) receptor: possible role of AT1 receptor dimerization. Cardiovasc Res (2008) 79:169-78. doi:10.1093/cvr/cvn064

65. Robert V, Heymes C, Silvestre JS, Sabri A, Swynghedauw B, Delcayre C. Angiotensin AT1 receptor subtype as a cardiac target of aldosterone: role in aldosterone-salt-induced fibrosis. Hypertension (1999) 33:981-6. doi:10.1161/ 01.HYP.33.4.981

66. Nishizaka MK, Pratt-Ubunama M, Zaman MA, Cofield S, Calhoun DA. Validity of plasma aldosterone-to-renin activity ratio in African American and white subjects with resistant hypertension. Am J Hypertens (2005) 18:805-12. doi:10.1016/j.amjhyper.2005.01.002

67. Pimenta E, Gaddam KK, Oparil S, Aban I, Husain S, Dell'Italia LJ, et al. Effects of dietary sodium reduction on blood pressure in subjects with resistant hypertension: results from a randomized trial. Hypertension (2009) 54:475-81. doi:10.1161/HYPERTENSIONAHA.109.131235

68. Graves JW, Bloomfield RL, Buckalew VM. Plasma volume in resistant hypertension: guide to pathophysiology and therapy. Am J Med Sci (1989) 298:361-5. doi:10.1097/00000441-198912000-00001

69. Gaddam KK, Nishizaka MK, Pratt-Ubunama MN, Pimenta E, Aban I, Oparil S, et al. Characterization of resistant hypertension: association 
between resistant hypertension, aldosterone, and persistent intravascular volume expansion. Arch Intern Med (2008) 168:1159-64. doi:10.1001/archinte. 168.11.1159

70. Taler SJ, Textor SC, Augustine JE. Resistant hypertension: comparing hemodynamic management to specialist care. Hypertension (2002) 39:982-8. doi:10. 1161/01.HYP.0000016176.16042.2F

71. Labeit AM, Klotsche J, Pieper L, Pittrow D, Einsle F, Stalla GK, et al. Changes in the prevalence, treatment and control of hypertension in Germany? A clinicalepidemiological study of 50.000 primary care patients. PLoS One (2012) 7:e52229. doi:10.1371/journal.pone.0052229

72. Esler M, Straznicky N, Eikelis N, Masuo K, Lambert G, Lambert E. Mechanisms of sympathetic activation in obesity-related hypertension. Hypertension (2006) 48:787-96. doi:10.1161/01.HYP.0000242642.42177.49

73. Rossi GP, Belfiore A, Bernini G, Fabris B, Caridi G, Ferri C, et al. Body mass index predicts plasma aldosterone concentrations in overweight-obese primary hypertensive patients. J Clin Endocrinol Metab (2008) 93:2566-71. doi:10.1210/jc.2008-0251

74. Lloberes P, Lozano L, Sampol G, Romero O, Jurado MJ, Rios J, et al. Obstructive sleep apnoea and 24-h blood pressure in patients with resistant hypertension. J Sleep Res (2010) 19:597-602. doi:10.1111/j.1365-2869.2010.00839.x

75. Goncalves SC, Martinez D, Gus M, de Abreu-Silva EO, Bertoluci C, Dutra I, et al. Obstructive sleep apnea and resistant hypertension: a case-control study. Chest (2007) 132:1858-62. doi:10.1378/chest.07-1170

76. Gonzaga CC, Gaddam KK, Ahmed MI, Pimenta E, Thomas SJ, Harding SM, et al. Severity of obstructive sleep apnea is related to aldosterone status in subjects with resistant hypertension. J Clin Sleep Med (2010) 6:363-8.

77. Lozano L, Tovar JL, Sampol G, Romero O, Jurado MJ, Segarra A, et al. Continuous positive airway pressure treatment in sleep apnea patients with resistant hypertension: a randomized, controlled trial. J Hypertens (2010) 28:2161-8. doi:10.1097/HJH.0b013e32833b9c63

78. Parati G, Lombardi C, Hedner J, Bonsignore MR, Grote L, Tkacova R, et al. Position paper on the management of patients with obstructive sleep apnea and hypertension: joint recommendations by the European society of hypertension, by the European respiratory society and by the members of European Cost (cooperation in scientific and technological RESEARCH) ACTION B26 on obstructive sleep apnea. J Hypertens (2012) 30:633-46. doi:10.1097/HJH.0b013e328350e53b

79. Gaddam K, Pimenta E, Thomas SJ, Cofield SS, Oparil S, Harding SM, et al. Spironolactone reduces severity of obstructive sleep apnoea in patients with resistant hypertension: a preliminary report. JHum Hypertens (2010) 24:532-7. doi:10.1038/jhh.2009.96

80. Mente A, O’Donnell MJ, Rangarajan S, McQueen MJ, Poirier P, Wielgosz A, et al. Association of urinary sodium and potassium excretion with blood pressure. N Engl J Med (2014) 371:601-11. doi:10.1056/NEJMoa1311989

81. He FJ, MacGregor GA. Effect of modest salt reduction on blood pressure: a meta-analysis of randomized trials. Implications for public health. J Hum Hypertens (2002) 16:761-70. doi:10.1038/sj.jhh.1001459

82. Dimeo F, Pagonas N, Seibert F, Arndt R, Zidek W, Westhoff TH. Aerobic exercise reduces blood pressure in resistant hypertension. Hypertension (2012) 60:653-8. doi:10.1161/HYPERTENSIONAHA.111.00058

83. Law MR, Wald NJ, Morris JK, Jordan RE. Value of low dose combination treatment with blood pressure lowering drugs: analysis of 354 randomised trials. BMJ (2003) 326:1427. doi:10.1136/bmj.326.7404.1427

84. Wald DS, Law M, Morris JK, Bestwick JP, Wald NJ. Combination therapy versus monotherapy in reducing blood pressure: meta-analysis on 11,000 participants from 42 trials. Am J Med (2009) 122:290-300. doi:10.1016/j.amjmed. 2008.09.038

85. Ogawa H, Kim-Mitsuyama S, Matsui K, Jinnouchi T, Jinnouchi H, Arakawa $\mathrm{K}$, et al. Angiotensin II receptor blocker-based therapy in Japanese elderly, high-risk, hypertensive patients. Am J Med (2012) 125:981-90. doi:10.1016/ j.amjmed.2011.12.010

86. Peterzan MA, Hardy R, Chaturvedi N, Hughes AD. Meta-analysis of doseresponse relationships for hydrochlorothiazide, chlorthalidone, and bendroflumethiazide on blood pressure, serum potassium, and urate. Hypertension (2012) 59:1104-9. doi:10.1161/HYPERTENSIONAHA.111.190637

87. Messerli FH, Bangalore S. Antihypertensive efficacy of aliskiren: is hydrochlorothiazide an appropriate benchmark? Circulation (2009) 119:371-3. doi:10.1161/CIRCULATIONAHA.108.828897
88. Messerli FH, Makani H, Benjo A, Romero J, Alviar C, Bangalore S. Antihypertensive efficacy of hydrochlorothiazide as evaluated by ambulatory blood pressure monitoring: a meta-analysis of randomized trials. J Am Coll Cardiol (2011) 57:590-600. doi:10.1016/j.jacc.2010.07.053

89. Gifford RW Jr, Kirkendall W, O'Connor DT, Weidman W. Office evaluation of hypertension. A statement for health professionals by a writing group of the council for high blood pressure research, American Heart Association. Circulation (1989) 79:721-31. doi:10.1161/01.CIR.79.3.721

90. Bisognano JD, Bakris G, Nadim MK, Sanchez L, Kroon AA, Schafer J, et al. Baroreflex activation therapy lowers blood pressure in patients with resistant hypertension: results from the double-blind, randomized, placebo-controlled rheos pivotal trial. J Am Coll Cardiol (2011) 58:765-73. doi:10.1016/j.jacc.2011. 06.008

91. Krum H, Schlaich M, Whitbourn R, Sobotka PA, Sadowski J, Bartus K, et al. Catheter-based renal sympathetic denervation for resistant hypertension: a multicentre safety and proof-of-principle cohort study. Lancet (2009) 373:1275-81. doi:10.1016/S0140-6736(09)60566-3

92. Symplicity HTN-2 Investigators, Esler MD, Krum H, Sobotka PA, Schlaich MP, Schmieder RE, et al. Renal sympathetic denervation in patients with treatment-resistant hypertension (The symplicity HTN-2 Trial): a randomised controlled trial. Lancet (2010) 376:1903-9. doi:10.1016/S01406736(10)62039-9

93. Bhatt DL, Kandzari DE, O’Neill WW, D’Agostino R, Flack JM, Katzen BT, et al. A controlled trial of renal denervation for resistant hypertension. N Engl J Med (2014) 370:1393-401. doi:10.1056/NEJMoa1402670

94. Rossi GP, Maiolino G. Mineralocorticoid receptor antagonism as an addon treatment for resistant hypertension. Hypertens Res (2014) 37:1029-31. doi:10.1038/hr.2014.139

95. Karlberg BE, Kagedal B, Tegler L, Tolagen K, Bergman B. Controlled treatment of primary hypertension with propranolol and spironolactone. A crossover study with special reference to initial plasma renin activity. Am J Cardiol (1976) 37:642-9. doi:10.1016/0002-9149(76)90409-4

96. Ogilvie RI, Piafsky KM, Ruedy J. Antihypertensive responses to spironolactone in normal renin hypertension. Clin Pharmacol Ther (1978) 24:525-30.

97. Kreeft JH, Larochelle P, Ogilvie RI. Comparison of chlorthalidone and spironolactone in low - renin essential hypertension. Can Med Assoc J (1983) 128:31-4.

98. Pratt JH, Eckert GJ, Newman S, Ambrosius WT. Blood pressure responses to small doses of amiloride and spironolactone in normotensive subjects. Hypertension (2001) 38:1124-9. doi:10.1161/hy1101.095010

99. Weinberger MH, Roniker B, Krause SL, Weiss RJ. Eplerenone, a selective aldosterone blocker, in mild-to-moderate hypertension. Am J Hypertens (2002) 15:709-16. doi:10.1016/S0895-7061(02)02957-6

100. Burgess ED, Lacourciere Y, Ruilope-Urioste LM, Oparil S, Kleiman JH, Krause S, et al. Long-term safety and efficacy of the selective aldosterone blocker eplerenone in patients with essential hypertension. Clin Ther (2003) 25:2388-404. doi:10.1016/S0149-2918(03)80282-5

101. White WB, Carr AA, Krause S, Jordan R, Roniker B, Oigman W. Assessment of the novel selective aldosterone blocker eplerenone using ambulatory and clinical blood pressure in patients with systemic hypertension. Am J Cardiol (2003) 92:38-42. doi:10.1016/S0002-9149(03)00461-2

102. Delyani JA. Mineralocorticoid receptor antagonists: the evolution of utility and pharmacology. Kidney Int (2000) 57:1408-11. doi:10.1046/j.1523-1755.2000. 00983.x

103. Flack JM, Oparil S, Pratt JH, Roniker B, Garthwaite S, Kleiman JH, et al. Efficacy and tolerability of eplerenone and losartan in hypertensive black and white patients. J Am Coll Cardiol (2003) 41:1148-55. doi:10.1016/S0735-1097(03) 00054-8

104. Weinberger MH, White WB, Ruilope LM, MacDonald TM, Davidson RC, Roniker B, et al. Effects of eplerenone versus losartan in patients with low-renin hypertension. Am Heart J (2005) 150:426-33. doi:10.1016/j.ahj. 2004.12.005

105. Williams GH, Burgess E, Kolloch RE, Ruilope LM, Niegowska J, Kipnes MS, et al. Efficacy of eplerenone versus enalapril as monotherapy in systemic hypertension. Am J Cardiol (2004) 93:990-6. doi:10.1016/j.amjcard.2004.01.007

106. Pitt B, Reichek N, Willenbrock R, Zannad F, Phillips RA, Roniker B, et al. Effects of eplerenone, enalapril, and eplerenone/enalapril in patients with essential hypertension and left ventricular hypertrophy: the $4 \mathrm{E}-\mathrm{left}$ 
ventricular hypertrophy study. Circulation (2003) 108:1831-8. doi:10.1161/01. CIR.0000091405.00772.6E

107. White WB, Duprez D, St Hillaire R, Krause S, Roniker B, Kuse-Hamilton J, et al. Effects of the selective aldosterone blocker eplerenone versus the calcium antagonist amlodipine in systolic hypertension. Hypertension (2003) 41:1021-6. doi:10.1161/01.HYP.0000067463.13172.EA

108. Krum H, Nolly H, Workman D, He W, Roniker B, Krause S, et al. Efficacy of eplerenone added to renin-angiotensin blockade in hypertensive patients. Hypertension (2002) 40:117-23. doi:10.1161/01.HYP.0000025146.19104.FE

109. Ando K, Ohtsu H, Uchida S, Kaname S, Arakawa Y, Fujita T, et al. Antialbuminuric effect of the aldosterone blocker eplerenone in non-diabetic hypertensive patients with albuminuria: a double-blind, randomised, placebocontrolled trial. Lancet Diabetes Endocrinol (2014) 2:944-53. doi:10.1016/ S2213-8587(14)70194-9

110. Ouzan J, Perault C, Lincoff AM, Carre E, Mertes M. The role of spironolactone in the treatment of patients with refractory hypertension. Am J Hypertens (2002) 15:333-9. doi:10.1016/S0895-7061(01)02342-1

111. Nishizaka MK, Zaman MA, Calhoun DA. Efficacy of low-dose spironolactone in subjects with resistant hypertension. Am J Hypertens (2003) 16:925-30. doi:10.1016/S0895-7061(03)01032-X

112. Sharabi Y, Adler E, Shamis A, Nussinovitch N, Markovitz A, Grossman E. Efficacy of add-on aldosterone receptor blocker in uncontrolled hypertension. Am J Hypertens (2006) 19:750-5. doi:10.1016/j.amjhyper.2005.11.016

113. Lane DA, Shah S, Beevers DG. Low-dose spironolactone in the management of resistant hypertension: a surveillance study. J Hypertens (2007) 25:891-4. doi:10.1097/HJH.0b013e328014954d

114. Saha C, Eckert GJ, Ambrosius WT, Chun TY, Wagner MA, Zhao Q, et al. Improvement in blood pressure with inhibition of the epithelial sodium channel in blacks with hypertension. Hypertension (2005) 46:481-7. doi:10.1161/ 01.HYP.0000179582.42830.1d

115. Chapman N, Dobson J, Wilson S, Dahlof B, Sever PS, Wedel H, et al. Effect of spironolactone on blood pressure in subjects with resistant hypertension. Hypertension (2007) 49:839-45. doi:10.1161/01.HYP.0000259805.18468.8c

116. de Souza F, Muxfeldt E, Fiszman R, Salles G. Efficacy of spironolactone therapy in patients with true resistant hypertension. Hypertension (2010) 55:147-52. doi:10.1161/HYPERTENSIONAHA.109.140988

117. Colussi G, Catena C, Sechi LA. Spironolactone, eplerenone and the new aldosterone blockers in endocrine and primary hypertension. J Hypertens (2013) 31:3-15. doi:10.1097/HJH.0b013e3283599b6a

118. Marrs JC. Spironolactone management of resistant hypertension. Ann Pharmacother (2010) 44:1762-9. doi:10.1345/aph.1P338

119. Vaclavik J, Sedlak R, Plachy M, Navratil K, Plasek J, Jarkovsky J, et al. Addition of spironolactone in patients with resistant arterial hypertension (ASPIRANT): a randomized, double-blind, placebo-controlled trial. Hypertension (2011) 57:1069-75. doi:10.1161/HYPERTENSIONAHA.111.169961
120. Abolghasmi R, Taziki O. Efficacy of low dose spironolactone in chronic kidney disease with resistant hypertension. Saudi J Kidney Dis Transpl (2011) 22:75-8.

121. Oxlund CS, Henriksen JE, Tarnow L, Schousboe K, Gram J, Jacobsen IA. Low dose spironolactone reduces blood pressure in patients with resistant hypertension and type 2 diabetes mellitus: a double blind randomized clinical trial. J Hypertens (2013) 31:2094-102. doi:10.1097/HJH.0b013e3283638bla

122. Karns AD, Bral JM, Hartman D, Peppard T, Schumacher C. Study of aldosterone synthase inhibition as an add-on therapy in resistant hypertension. J Clin Hypertens (Greenwich) (2013) 15:186-92. doi:10.1111/jch.12051

123. Mahmud A, Mahgoub M, Hall M, Feely J. Does aldosterone-to-renin ratio predict the antihypertensive effect of the aldosterone antagonist spironolactone? Am J Hypertens (2005) 18:1631-5. doi:10.1016/j.amjhyper.2005.06.010

124. Shlomai G, Sella T, Sharabi Y, Leibowitz A, Grossman E. Serum potassium levels predict blood pressure response to aldosterone antagonists in resistant hypertension. Hypertens Res (2014) 37:1037-41. doi:10.1038/hr.2014.77

125. Prisant LM, Krum H, Roniker B, Krause SL, Fakouhi K, He W. Can renin status predict the antihypertensive efficacy of eplerenone add-on therapy? J Clin Pharmacol (2003) 43:1203-10. doi:10.1177/0091270003258189

126. Parthasarathy HK, Alhashmi K, McMahon AD, Struthers AD, McInnes GT, Ford $\mathrm{I}$, et al. Does the ratio of serum aldosterone to plasma renin activity predict the efficacy of diuretics in hypertension? Results of RENALDO. J Hypertens (2010) 28:170-7. doi:10.1097/HJH.0b013e328332b79b

127. Tan SY, Shapiro R, Franco R, Stockard H, Mulrow PJ. Indomethacin-induced prostaglandin inhibition with hyperkalemia. A reversible cause of hyporeninemic hypoaldosteronism. Ann Intern Med (1979) 90:783-5. doi:10.7326/00034819-90-5-783

Conflict of Interest Statement: The authors declare that the research was conducted in the absence of any commercial or financial relationships that could be construed as a potential conflict of interest.

Received: 15 October 2014; accepted: 12 January 2015; published online: 04 February 2015.

Citation: Maiolino G, Azzolini M and Rossi GP (2015) Mineralocorticoid receptor antagonists therapy in resistant hypertension: time to implement guidelines! Front. Cardiovasc. Med. 2:3. doi: 10.3389/fcrm.2015.00003

This article was submitted to Hypertension, a section of the journal Frontiers in Cardiovascular Medicine.

Copyright (๑) 2015 Maiolino, Azzolini and Rossi. This is an open-access article distributed under the terms of the Creative Commons Attribution License (CC BY). The use, distribution or reproduction in other forums is permitted, provided the original author(s) or licensor are credited and that the original publication in this journal is cited, in accordance with accepted academic practice. No use, distribution or reproduction is permitted which does not comply with these terms. 